\title{
Communication/Comunicação
}

\section{Characterization of a new coagulase-negative Staphylococcus species (Staphylococcus pettenkoferi) isolated from blood cultures from a hospitalized patient in Porto Alegre, Brazil}

\author{
Caracterização de uma nova espécie de Staphylococcus coagulase-negativo (Staphylococcus \\ pettenkofer) isolada de hemoculturas de um paciente hospitalizado em Porto Alegre, Brasil
}

\author{
Pedro Alves d'Azevedo ${ }^{1}$, Guilherme Comin ${ }^{1}$ and Vlademir Cantarelli ${ }^{2}$
}

\begin{abstract}
Introduction: Staphylococcus pettenkoferi was originally isolated and described by Trülzsch et al (2002). In this study, we characterized two isolates of this newly described species. Methods: Blood cultures were initially processed using the BacT/ALERT ${ }^{\circledR}$ device, and the isolates were initially characterized using the Vitek2 identification system. Results: The initial characterization revealed slow-growing Gram-positive cocci that formed opaque colonies on sheep blood agar. Other phenotypic/genotypic tests were performed. Conclusions: We would like to emphasize that this new staphylococcus species is phenotypically similar to other CoNS, especially S. auricularis. This could potentially lead to misidentification of these uncommon species.
\end{abstract}

Key-words: Coagulase-negative Staphylococcus. Blood culture. Staphylococcus pettenkoferi.

\section{RESUMO}

Introdução: Staphylococcus pettenkoferi foi originalmente isolado e descrito por Trülzsch et al (2002). Neste estudo, caracterizamos dois isolados dessa nova espécie. Métodos: As hemoculturas foram inicialmente processadas usando o instrumento BacT/ALERT ${ }^{\circledR}$ e os isolados foram inicialmente caracterizados pelo sistema de identificação Vitek2. Resultados: A caracterização inicial revelou um coco Gram-positivo de crescimento lento com formação de colônias opacas em agar sangue de carneiro. Outros testes fenotípicos/genotípicos foram realizados. Conclusões: Gostaríamos de enfatizar que esta nova espécie de Staphylococcus é fenotipicamente similar a outros CoNS, especialmente, S. auricularis, que poderia levar a um erro na identificação dessas espécies incomuns.

Palavras-chaves: Coagulase-negativo. Staphylococcus. Hemocultura. Staphylococcus pettenkoferi.

The genus Staphylococcus is currently composed of 37 species and subspecies that are ubiquitous in nature. Coagulase-negative staphylococci (CoNS) have become important nosocomial pathogens during the past few years, especially among patients with an orthopedic or cardiac prosthesis, patients with prolonged catheter use, immunocompromised patients or neonates ${ }^{1,2}$. Staphylococcus pettenkoferi was originally isolated and described by Trülzsch ${ }^{3}$ et al,

1. Laboratory of Gram-positive Cocci, University of Health Sciences of Porto Alegre, RS, Brazil. 2. Weinmann Laboratory, Porto Alegre, RS.

Address To: Dr. Pedro Alves d'Azevedo. UFCSPA. Rua Sarmento Leite 245/204. 90050-170 Porto Alegre, RS.

Tel: $55513303-8740$

e-mail: pedroaze@ufcspa.edu.br

Received in 08/03/2010

Accepted in 23/04/2010 but this species name has not yet been scientifically validated. In this study, we characterized two isolates of this newly described species that were recovered from blood cultures from a hospitalized patient in the city of Porto Alegre, Rio Grande do Sul, Brazil. The 56-yearold patient had been hospitalized for 45 days and tested positive in three blood culture sets in April 2008. The blood cultures were initially processed using the BacT/ALERT $®$ device (bioMérieux, l'Etoile, France) and the isolates were initially characterized by means of the Vitek2 identification system (bioMérieux). The device named the isolates Kocuria varians (formerly Micrococcus varians), which was not consistent with the characteristics of this species $^{4}$. As reported by Cunha et $\mathrm{al}^{5}$, some Staphylococcus strains have often been identified as Kocuria in using the Vitek2 system. Because of the atypical results, the isolates were further subjected to an extensive battery of conventional tests, along with molecular analysis, including DNA sequencing of $16 \mathrm{~S}$ rRNA and SodA genes $^{1,6}$. The initial characterization revealed slow-growing Grampositive cocci that formed opaque colonies on sheep blood agar. The other tests results included: weakly positive catalase reaction, negative coagulase reaction, sensitivity to novobiocin, resistance to desferroxamine, sensitivity to phosphomycin, resistance to bacitracin, positive for pyrrolidonyl arylamidase (PYR), positive for urease and positive for nitrate reductase. The DNase test using $1 \mathrm{~N}$ $\mathrm{HCl}$ was negative. Acid was produced only with glucose, fructose and sucrose, following up to seven days of incubation. Arginine arylamidase, ornithine decarboxylase and acetoin production were negative. Molecular characterization of the isolates were performed by means of sodA amplification using the polymerase chain reaction (PCR) followed by direct sequencing of the PCR products generated using BigDye-termination chemistry (Applied Biosystems), in order to better identify these isolates. Homology search (BLAST) demonstrated that the sequences generated were identical to those of Staphylococcus pettenkoferi. We would like to emphasize that this new staphylococcal species is phenotypically similar to other CoNS, especially S. auricularis. This could potentially lead to misidentification of this uncommon species.

\section{CONFLICT OF INTEREST}

The authors declare that there is no conflict of interest. 
FINANCIAL SUPPORT

This work was supported by Conselho Nacional de Desenvolvimento Científico e Tecnológico, Universidade Federal de Ciências da Saúde de Porto Alegre and Weinmann Laboratório.

\section{REFERENCES}

1. Bannerman TL, Peacook SJ. Staphylococcus, Micrococcus and other catalasepositive cocci. In: PR Murray, Baron EJ, Jorgensen JH, Pfaller MA, Yolken RH, editors. Manual of Clinical Microbiology, $8^{\text {th }}$ ed. Am Soc Microbiol; 2007. p. 390-411.

2. Loïez C, Wallet F, Pischedda P, Renaux E, Senneville E, Mehdi N, et al. First case of osteomyelitis caused by "Staphylococcus pettenkoferi". J Clin Microbiol 2007; 45:1069-1071.

3. Trülzsch K, Rinder H, Trcek J, Bader L, Wilhelm U, Heesemann J. Staphylococcus pettenkoferi a novel staphylococcal species isolated from clinical specimens. Diag Microbiol Infect Dis 2002; 43:175-182.

4. Tvrzová L, Schumann P, Sedlácek I, Pácová Z, Spröer C, Verbarg S, et al. Reclassification of strain CCM 132, previously classified as Kocuria varians, as Kocuria carniphila sp. nov. Int J Syst Evol Microbiol 2005; 55:139-142.

5. Cunha ML, Sinzato YK, Silveira LV. Comparison of methods for the identification of coagulase-negative staphylococci. Mem Inst Oswaldo Cruz 2004; 99:855860 .

6. Trülzsch K, Grabein B, Schumann P, Mellmann A, Antonenka U, Heesemann J, et al. Staphylococcus pettenkoferi sp. nov., a novel coagulase-negative staphylococcal species isolated from human clinical specimens. Int J Syst Evol Microbiol 2007; $57: 1543-1548$ 